\title{
Comparative Study on Analysis and Design between Flat Slab and Flat Plate System for RC Building
}

\author{
Phyoe Hnin Thu Htun \\ Department of Civil Engineering \\ Technological University \\ (Thanlyin),
}

Myanmar

\author{
Nyan Phone \\ Department of Civil Engineering \\ Technological University \\ (Thanlyin), \\ Myanmar
}

\author{
Kyaw Zeyar Win \\ Department of Civil Engineering \\ Technological University \\ (Thanlyin), \\ Myanmar
}

\begin{abstract}
During recent years, the flat slab and flat plate building construction have become popular in Myanmar. These slab systems have many benefits which enhance speeding up construction, low building height and economical. In this study, the $12 \frac{1}{2} \mathrm{storeyed} \mathrm{RC}$ building with flat slab system and flat plate system have been analysed by ETABS. Flat slab and flat plate are designed by SAFE software. Both structures are situated in seismic zone $2 \mathrm{~B}$. The purpose of the research is to compare the structural behaviour of both structure such as base shear, story drift and story displacement. Moreover, another purpose is to present the difference between slab stresses and slab design. Load considerations are based on UBC-97 and structural elements are designed according to ACI 318-08.For these 121/2 storeyed RC building, the comparison results show that the flat plate building is more beneficial than flat slab building. As the structural behaviour of flat plate building is better stiffness than flat slab building, flat plate building is safer. Moreover, flat plate building is more economical so steel area of flat plate building is less than flat slab building.
\end{abstract}

Keywords: Flat Slab System, Flat Plate System, Base Shear, Story Drift, Story Displacement, Slab Stresses, Slab Design

\section{INTRODUCTION}

There are different kinds of reinforced concrete floor systems. Among many slab systems, flat slab and flat plate system are widely used in construction. A reinforced concrete slab supported directly by columns without the use of beams or girder, such a slab is called flat slab. Provision of thickened portion of slab around column is called drop panel that provides to reduce stresses due to shear and negative bending moment around the columns. It is a rectangular or square region centered on the column. Slabs of constant thickness which do not drop panels or column capitals is called flat plate. The slab directly rests on column and load from the slab is directly transferred to the columns and then to be foundation. The flat slab and flat plate are weak to resist the lateral loads. Since these slabs are carried directly by column, transferring from slab to column through shear increase and the slabs have to be failure due to punching shear. RCC flat slab structure is investigated the behavior of flat slab during the earthquakes and checked for increase of punching from gravity loads to earthquake loads and examined tendency of punching shear failure in flat slabs [1] .Many research studied the structural behavior of flat slab structures under seismic zones by using ETABS software and compared with other slab systems [2-4]. Flat slabs are being used chiefly in office buildings and residential buildings due to reduced formwork cost, fast excavation and easy establishment. The quantity of concrete and steel required and the structural behavior of flat slab are studied and compared with grid slab and conventional slab system [5]. The structural efficiency of the flat slab construction is poor under earthquake loadings because it has low stiffness. The shear walls are placed at suitable locations and it can be used to improve efficiency of flat slab with column structure in earthquake zones. The behavior of flat slab structure with shear wall is better than flat slab structure without shear wall [6]. In the analysis of a flat slab structure which subject to gravity loads, direct design method or equivalent frame method is generally used for the rectangular slabs while commercial software such as SAFE [7]. In this paper, the structural behavior of flat slab system and flat plate system are studied and compared by using ETABS software in linear static analysis. The slabs are designed and the differences of slab stresses are studied by applying SAFE software. The provision of this research is that the flat plate system for residential building is more suitable than the flat slab system depending upon the comparison of story drift, base shear, story displacement, slab stresses and slab reinforcement.

\section{TYPE OF STRUCTURE}

The $12^{1 / 2}$ storeyed $\mathrm{RC}$ building is considered with two slab system.

1. Flat slab structure with drop panels without parameter beam

2. Flat plate structure without drop panels with parameter beam

Both structures are designed with the same column, slab thickness and shear wall. Since these structures are low stiffness, shear walls are placed at suitable locations. Penthouse is located on the roof, so prop columns and roof beam system are used in this floor for both buildings. Rectangular columns are used depending on shape of structure.

Table 1. Material Specification

\begin{tabular}{|c|c|}
\hline Concrete compressive strength $\left(\mathrm{f}_{\mathrm{c}}{ }^{\prime}\right)$ & $4 \mathrm{ksi}$ \\
\hline Reinforcing yield strength $\left(\mathrm{f}_{\mathrm{y}}\right)$ & $50 \mathrm{ksi}$ \\
\hline Modulus of Elasticity & $3605 \mathrm{ksi}$ \\
\hline Poisson's ratio & 0.2 \\
\hline
\end{tabular}

Table 2. Structural Plan Details 


\begin{tabular}{|c|c|}
\hline Number of stories & $12^{1 / 2}$ \\
\hline Width of structure & $63^{\prime}-6^{\prime \prime}$ \\
\hline Length of structure & $96^{\prime}$ \\
\hline Total height of structure & $139^{\prime}-6^{\prime \prime}$ \\
\hline Typical story height & $10^{\prime}-6^{\prime \prime}$ \\
\hline GF and 1F height & $12^{\prime \prime}$ \\
\hline Number of bay's along X & 4 \\
\hline Number of bay's along Y & 4 \\
\hline
\end{tabular}

Table 3. Structure Element Details

\begin{tabular}{|c|c|}
\hline Column sizes & $\begin{array}{r}14^{\prime \prime} \times 20^{\prime \prime}, 14^{\prime \prime} \times 24^{\prime \prime}, 14^{\prime \prime} 28^{\prime \prime}, 14^{\prime \prime} \times 30^{\prime \prime} \\
16^{\prime \prime} \times 32^{\prime \prime}, 18^{\prime \prime} \times 28^{\prime \prime}, 18^{\prime \prime} \times 34^{\prime \prime},\end{array}$ \\
\hline Beam sizes & $16^{\prime \prime} \times 24^{\prime \prime}, 14^{\prime \prime} \times 20^{\prime \prime}, 12^{\prime \prime} \times 15^{\prime \prime}$ \\
\hline Slab thickness & $8^{\prime \prime}$ \\
\hline Drop thickness & $12^{\prime \prime}$ \\
\hline Drop size & $6{ }^{\prime} \times 8^{\prime}$ \\
\hline Shear wall thickness & $12^{\prime \prime}$ \\
\hline
\end{tabular}

\section{MODEL DESCRIPTION}

The figure (1) shows 3D view of flat slab building and flat plate building. The figure (2) and (3) show the typical floor plan of both building.

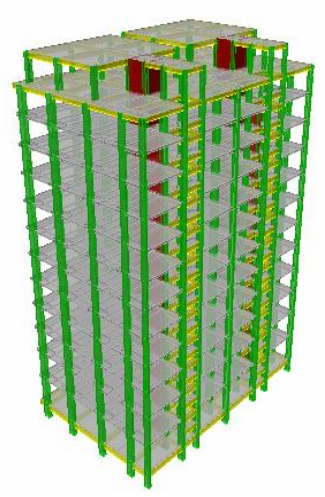

(i) Flat Slab System

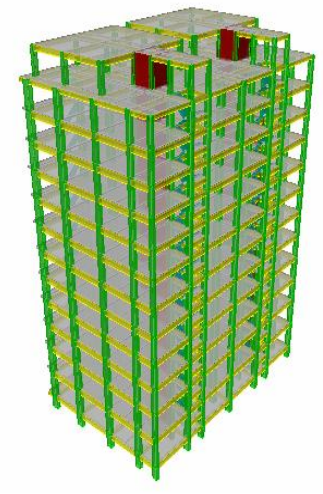

(ii) Flat Plate System
Figure 1.3D View of Building

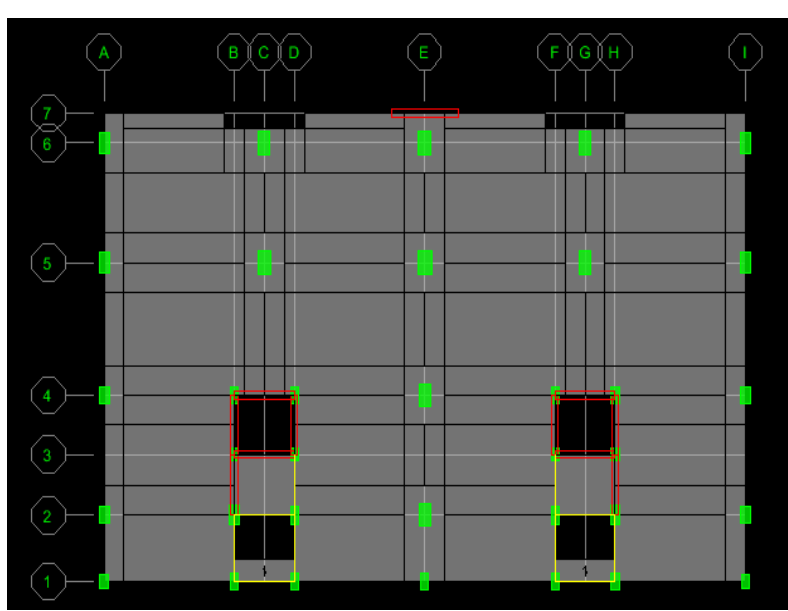

Figure 2. Typical Floor Plan of Flat Slab Building

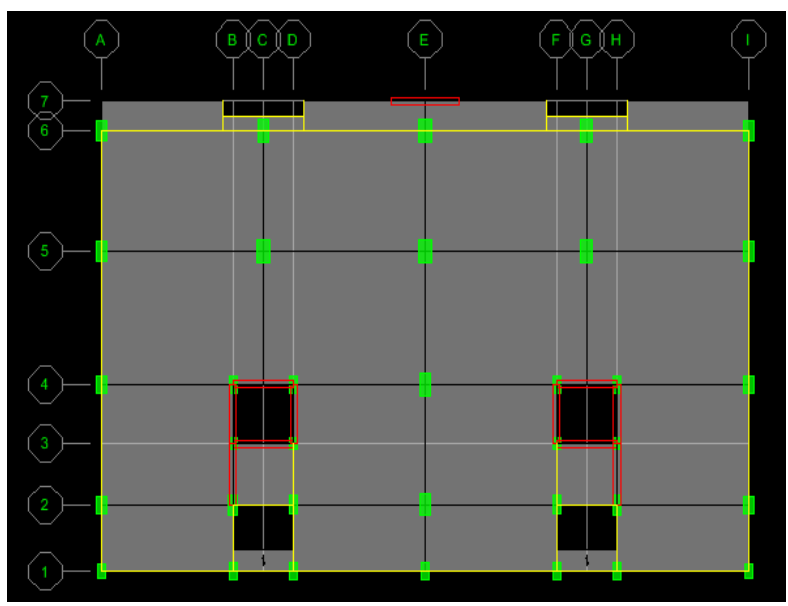

Figure 3. Typical Floor Plan of Flat Plate Building

\section{RESULTS AND DISCUSSION}

In this section the results obtained from the analysis of flat slab building and flat plate building using ETABS and SAFE software have been tabulated and compared. The performance and behavior of both structure on different criteria like story shear, story displacement, story drift, slab stresses, and slab reinforcement has been analyzed and discussed as follow.

\subsection{Story Shear}

The figure (4) and (5) show the comparison of story shear in $\mathrm{X}$-direction and $\mathrm{Y}$-direction.

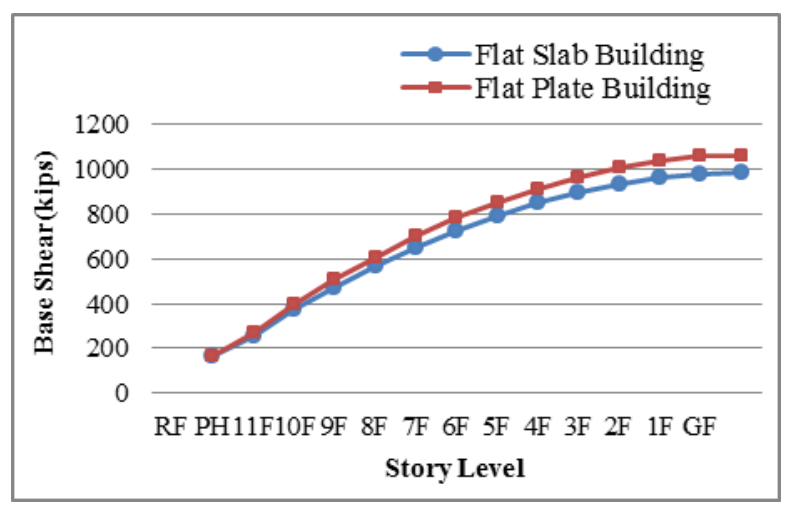

Figure 4. Comparison of Story Shear in X-Direction 


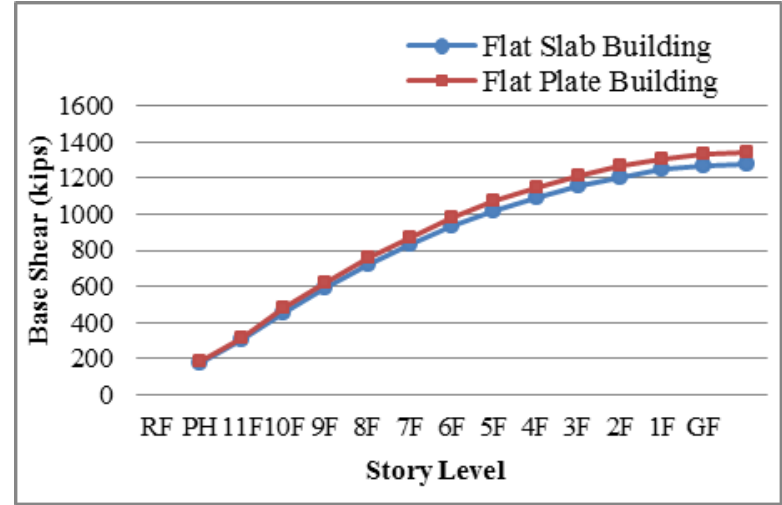

Figure 5. Comparison of Story Shear in Y-Direction

Above the figures show that the comparison of story shear values for flat slab and flat plate building. From the above results, it can be seen that the value of story shear of flat plate building is slightly more than that of flat slab building. Because the value of story shear depends upon the weight of the structure. The weight of flat plate building is more slightly than that of flat slab building. The story shear value is maximum at ground floor level and is gradually decreasing towards to the top story of structure. The difference of story shear in X-direction for both building is slightly more than $\mathrm{Y}$ direction.

\subsection{Story Drift}

The figure(6) and (7) show the comparison of story displacement in $\mathrm{X}$-direction and Y-direction.

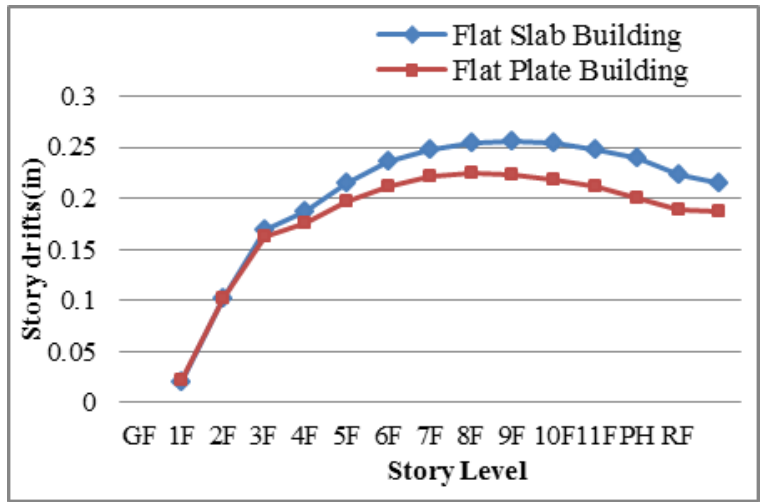

Figure 6. Comparison of Story Drift in X-Direction

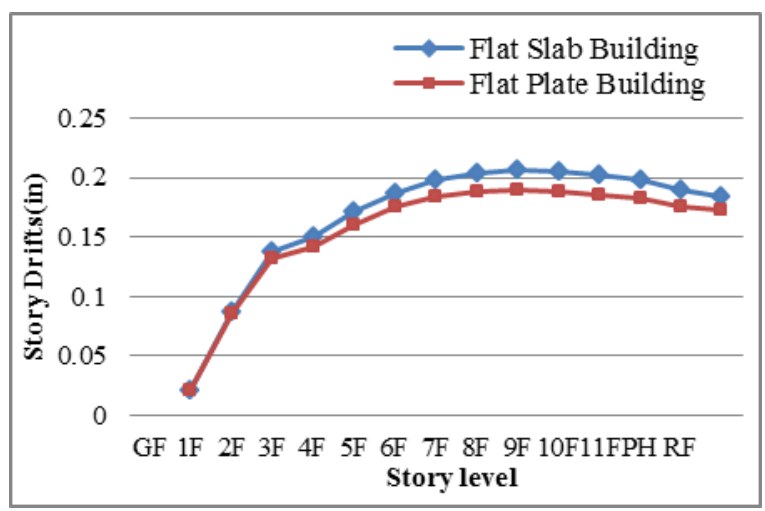

Figure 7. Comparison of Story Drift in Y-Direction
Story drift is the lateral displacement of one level relative to the level above or below. Story drift ratio is the story drift divided by the story height which is described in UBC97(Chapter-16). Above the results have been tabulated and compared and it can be seen that the story drift of flat slab building is more than that of flat plate building. The story drift is minimum at ground floor level, increase at the middle stories and gradually decrease to the top stories of both structures.

\subsection{Story Displacement}

The figure(8) and (9) show the comparison of story displacement in X-direction and y- direction.

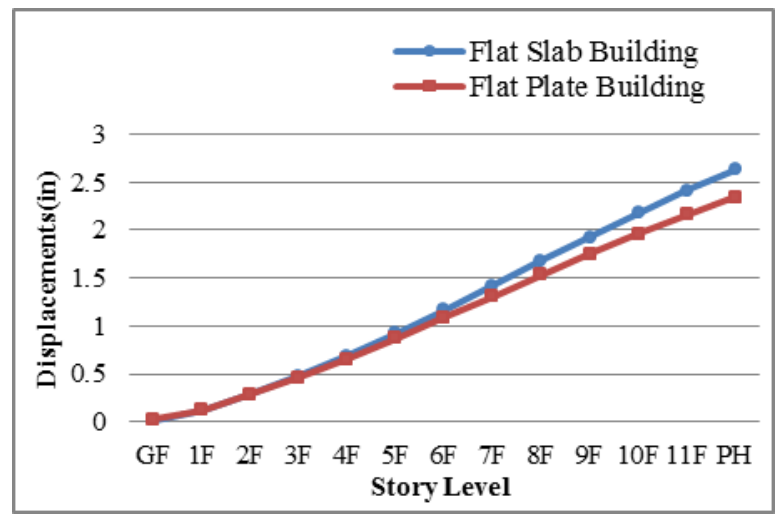

Figure 8. Comparison of Story Displacement in X-Direction

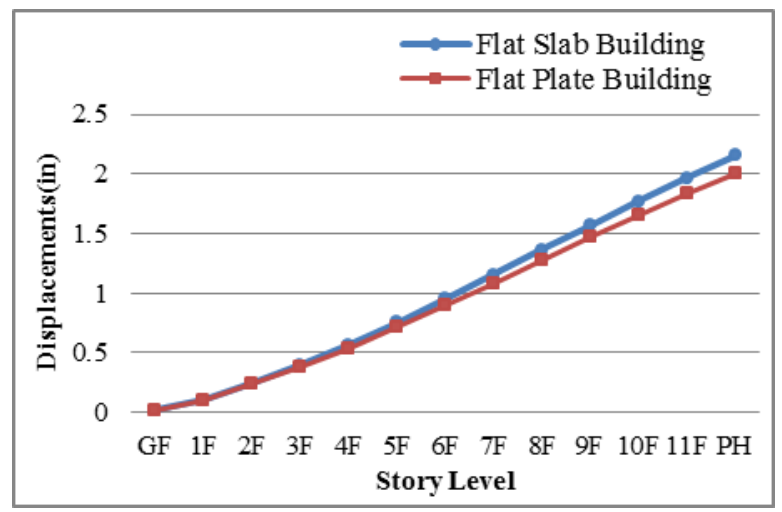

Figure 9. Comparison of Story Displacement in Y-Direction

From above figures, it can be seen that the story displacement of flat slab building is more than that of flat plate building. The displacement is dependent on the structure stiffness. The stiffness of flat plate building is better than that of flat slab building as the flat plate building is designed with perimeter beam and shear wall. Although the flat slab building is designed with drop panel and shear wall to have safe stiffness, it is less stiffness than flat plate building. Provision of drop panel to flat slab, story displacement reduces slightly. The thicker the drop panel, the more increase the stiffness. The story displacement is maximum at top story and minimum at ground floor.

\subsection{Slab Deflection}

From the figure.10 shows that the deflection of flat plate is a little more than that of flat slab. Slab deflection depends on slab thickness. As both buildings are the same slab thickness, the differences of deflection values are nearly equal. The 
deflection is maximum at eleventh floor and all of the rest floors have nearly the same deflection values.

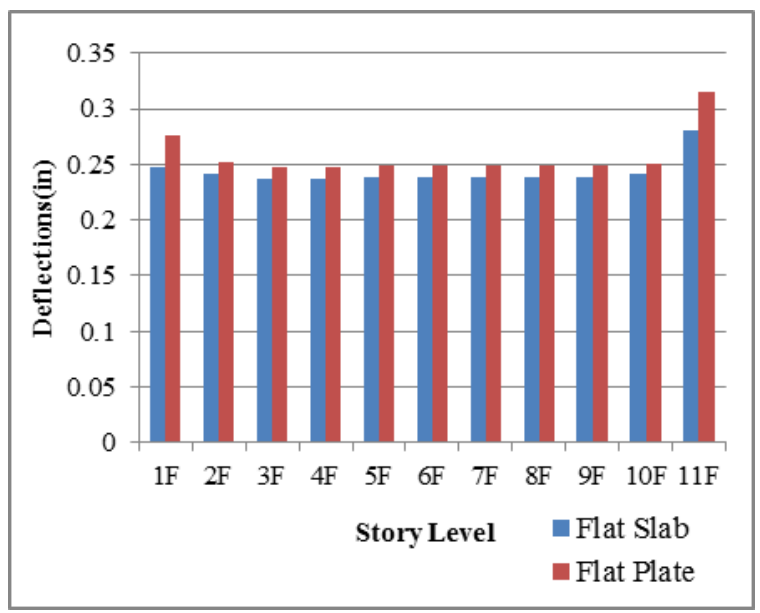

Figure 10. Comparison of Slab Deflection

\subsection{Punching Shear Strength}

Punching shear can occur around the column in flat plate and flat slab and failure can be occurred by it. The figure(11) shows that the comparison of punching shear strength of interior column in flat plate and flat slab building, it can be seen that the punching shear strength of flat slab is more than that of flat plate because the flat slab includes drop panel that increase shear strength. Punching shear strength depends on drop panel. However, the corner column in flat slab building is weak to resist punching shear as the perimeter of the reaction area is less. In flat plate building, as perimeter beams are provided, the corner columns don't suffer punching shear but it is affected by beam shear. The punching shear strength gradually increases towards the top floors.

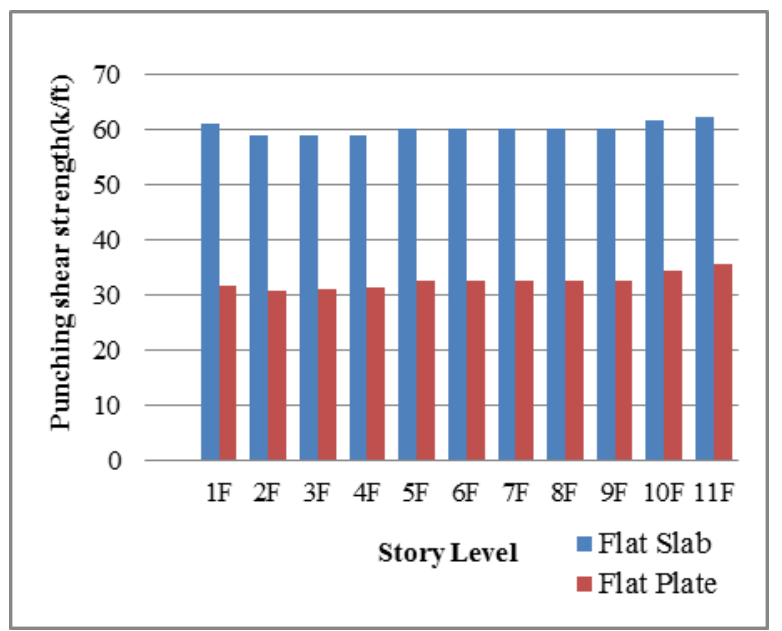

Figure 11. Comparison of Punching Shear Strength

\subsection{Moment on Slab}

The following figure(12) shows that moment of flat slab is more than that of flat plate. The moment at first floor and eleventh floor is large and all of the rest floors have not significantly difference.

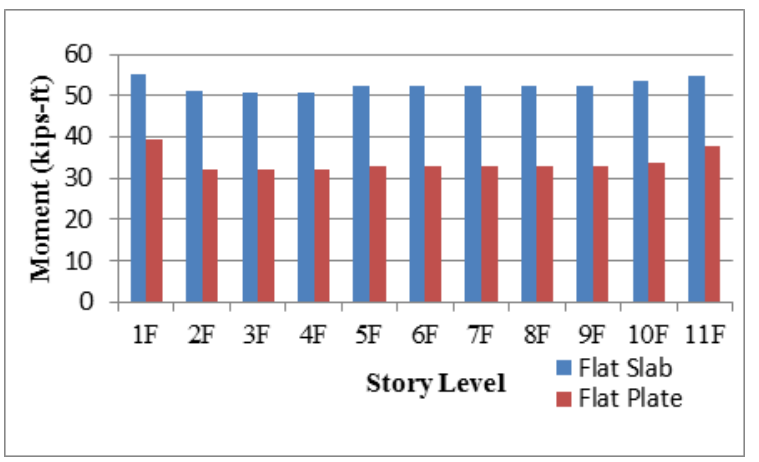

Figure 12. Comparison of Moment on Slab

\subsection{Slab Reinforcement}

Table 4. Comparison of Slab Reinforcement

\begin{tabular}{|c|c|c|c|c|}
\hline Story & Layer & & $\begin{array}{c}\text { Flat Slab } \\
\left(\mathrm{in}^{2} / \mathrm{ft}\right)\end{array}$ & $\begin{array}{c}\text { Flat Plate } \\
\left(\mathrm{in}^{2} / \mathrm{ft}\right)\end{array}$ \\
\hline \multirow{4}{*}{$1 \mathrm{~F}$} & \multirow{2}{*}{ Layer A } & Top & 0.5366 & 0.6259 \\
\hline & & Bottom & 0.269 & 0.2358 \\
\hline & \multirow{2}{*}{ Layer B } & Top & 0.7886 & 0.7736 \\
\hline & & Bottom & 0.3974 & 0.3844 \\
\hline \multirow{4}{*}{$2 \mathrm{~F}$} & \multirow{2}{*}{ Layer A } & Top & 0.5104 & 0.5487 \\
\hline & & Bottom & 0.2586 & 0.1925 \\
\hline & \multirow{2}{*}{ Layer B } & Top & 0.766 & 0.7117 \\
\hline & & Bottom & 0.3886 & 0.3533 \\
\hline \multirow{4}{*}{$3 \mathrm{~F}$} & \multirow{2}{*}{ Layer A } & Top & 0.5151 & 0.5469 \\
\hline & & Bottom & 0.2564 & 0.1915 \\
\hline & \multirow{2}{*}{ Layer B } & Top & 0.7869 & 0.6931 \\
\hline & & Bottom & 0.3849 & 0.3473 \\
\hline \multirow{4}{*}{$4 \mathrm{~F}$} & \multirow{2}{*}{ Layer A } & Top & 0.5151 & 0.547 \\
\hline & & Bottom & 0.2564 & 0.1916 \\
\hline & \multirow{2}{*}{ Layer B } & Top & 0.7874 & 0.6933 \\
\hline & & Bottom & 0.3849 & 0.3473 \\
\hline \multirow{4}{*}{$5 \mathrm{~F}$} & \multirow{2}{*}{ Layer A } & Top & 0.5252 & 0.5648 \\
\hline & & Bottom & 0.2537 & 0.1927 \\
\hline & \multirow{2}{*}{ Layer B } & Top & 0.7615 & 0.7103 \\
\hline & & Bottom & 0.387 & 0.3494 \\
\hline \multirow{4}{*}{$6 \mathrm{~F}$} & \multirow{2}{*}{ Layer A } & Top & 0.5252 & 0.5648 \\
\hline & & Bottom & 0.2537 & 0.1927 \\
\hline & \multirow{2}{*}{ Layer B } & Top & 0.7615 & 0.7103 \\
\hline & & Bottom & 0.387 & 0.3494 \\
\hline \multirow{4}{*}{$7 F$} & \multirow{2}{*}{ Layer A } & Top & 0.5252 & 0.5648 \\
\hline & & Bottom & 0.2537 & 0.1927 \\
\hline & \multirow{2}{*}{ Layer B } & Top & 0.7615 & 0.7103 \\
\hline & & Bottom & 0.387 & 0.3494 \\
\hline \multirow{4}{*}{$8 \mathrm{~F}$} & \multirow{2}{*}{ Layer A } & Top & 0.5252 & 0.5648 \\
\hline & & Bottom & 0.2537 & 0.1927 \\
\hline & \multirow{2}{*}{ Layer B } & Top & 0.7615 & 0.7103 \\
\hline & & Bottom & 0.387 & 0.3494 \\
\hline & & Top & 0.5252 & 0.5648 \\
\hline $9 \mathrm{~F}$ & Layer A & Bottom & 0.2537 & 0.1927 \\
\hline $9 \mathrm{~F}$ & Laver $\mathrm{B}$ & Top & 0.7615 & 0.7103 \\
\hline & Layer в & Bottom & 0.387 & 0.3494 \\
\hline & & Top & 0.5328 & 0.5831 \\
\hline $10 \mathrm{~F}$ & Layer A & Bottom & 0.2509 & 0.1946 \\
\hline $10 \mathrm{~F}$ & I over P & Top & 0.7671 & 0.7295 \\
\hline & Layer B & Bottom & 0.3902 & 0.3514 \\
\hline & & Top & 0.5758 & 0.5473 \\
\hline & Layer A & Bottom & 0.2194 & 0.1919 \\
\hline $11 \mathrm{~F}$ & & Top & 0.8187 & 0.6346 \\
\hline & Layer B & Bottom & 0.3651 & 0.3387 \\
\hline
\end{tabular}


The slab design is considered ACI Code methods that a typical panel is divided, for purposes of design, into column strip and middle strip. Column strip is a design strip with a width on each side of a column centerline equal to $0.251_{2}$ or $0.251_{1}$, whichever is less. Middle strip is a design strip bounded by two column strips (ACI 318-08). The table shows that most of the steel area of flat slab is more than that of flat plate. The steel area of every floor in top steel of layer A in flat plate is larger than that of flat slab. The steel areas of almost all typical floors are equal. Variation of steel area depends upon the difference of moment.

\section{CONCLUSION}

1. Story shear in flat plate structure is more than flat slab structure and the shear value in $\mathrm{X}$-direction is more than Y-direction.

2. Story drift and displacement in flat slab is more than flat plate because of difference use of perimeter beams and drop panels. Both values in Y-direction is less than $\mathrm{X}$-direction as structure stiffness in $\mathrm{Y}$-direction is stronger by providing rectangular column and shear wall.

3. The punching shear failure occurs more in flat plate. The difference of punching strength in interior column is nearly $50 \%$ between flat slab and flat plate. But corners column in flat slab, punching shear strength is weak and shear reinforcement and drop thickness will be considered. Provision of shear wall and column size may not effective in reducing punching shear stress.

4. The difference of moment values in flat slab and flat plate is nearly $40 \%$ and this may be effective the difference of steel area.

Considering all the above inference on analysis of flat slab and flat plate system, the flat plate system is safer than flat slab system according to comparison of structural behavior. And flat plate system is more economical than flat slab system for this residential RC building by comparing steel area of both slabs.

\section{ACKNOWLEDGMENTS}

The author wishes to express the deepest thanks and gratitude to her supervisor Dr. Nyan Phone, Professor and Head of Civil Engineering Department of Technological University (Thanlyin). The author special thanks go to her co-supervisor Dr. Kyaw Zeyar Win, Professor of Civil Engineering Department of Technological University (Thanlyin), for his invaluable advice and effective suggestion throughout the study. The author would like to express her thanks to her member Dr. Kyaw Lin Htat, Professor of Civil Engineering Department of Technological University (Thanlyin), for his valuable comments and indispensable guidance during this study. Finally, her special thanks to all who helped her towards the successful completion of this study.

\section{REFERENCES}

[1] M.Rajagopal Reddy 1. P.Rajesh 2. "Design of RCC Flat Slab Structure Under Earthquake Loading Using Etabs".

[2] P. Srinivasulu, A. Dattatreya Kumar. (2015) "Behaviour of RCC Flat Slab Structure Under Earthquake Loading", IJSER, Vol-5, Issue-7, 821-829.

[3] Mohana H.S, Kavan M.R. (2015) "Comparative Study of Flat Slab and Conventional Slab Structure Using ETABS for Different Earthquake Zones of India". (IRJET), Vol2, Issue-7.

[4] Sakshwari Guruprasad T N Raghu K S (2016) "Comparative Study on Conventional Beam Slab and Flat Slab under Various Seismic Zones and Soil Conditions". (IRJET), Vol-3, Page: 1768-1774.

[5] Sudhir Singh Bhaduria, Nitin Chhugani. "Comparative Analysis and Design of Flat and Grid Slab System with Conventional Slab System". (IRJET), Vol-4, Issue; 08, Aug-2017.

[6] Niharika .M. Keskar, Dr.S.P.Raut. "Comparative Study of Mult-Storey RC Building Having Flat Slab with and without Shear wall with Conventional Frame Structure Subjected to Earthquake". International Journal of Advances in Scientific Research and Engineering (ijasre), Vol. 03, Issue 3, April-2017.

[7] Gaurav Ravindra Chavan, Dr. S. N. Tande. "Analysis and Design of Flat Slab". International Journal of Latest Trends in Engineering and Technology (IJTET), Vol-7, Issue 1, May 2016.

[8] Arthur H.Nilson. Design of Concrete Structures". Twelfth edition.

[9] M.Anitha B.Q.Rahman JJ.Vijay. "Analysis and Design of Flat Slabs Using Various Codes". International Institude of Information Technology Hyderabad. April 2007.

[10] U Nyi Hla Nge, "Reinforced Concrete Design". 